\title{
METODE MEMBANGKITKAN MINAT BELAJAR SISWA
}

Oleh : Pagga ${ }^{1}$

\begin{abstract}
Abstrak
Metode mengajar adalah adalah suatu pengetahuan tentang cara-cara mengajar yang dipergunakan oleh seorang guru atau instruktur. Pengertian lain ialah teknik pengajaran yang dikuasai guru untuk mengajar atau menyajikan bahan pelajaran kepada siswa di dalam kelas, baik secara individual maupun secara klasik, agar pelajaran itu dapat diserap, dipahami, dan dimanfaatkan oleh siswa dengan baik. Sedangkan prinsip-prinsip mengajar meliputi prinsip motivasi dan tujuan, prinsip taraf kematangan dan perbedaan individu, prinsip peluang praktis, dan prinsip proses belajar mengajar dan menggembirakan. Metode efktif untuk memberikan stimuli minat belajar siswa, maka seorang guru harus memperhatikan dua fakyor, yaitu faktor intern siswa, yaitu segala sesuatu yang berkaitan dengan hal-hal yang bersumber dari dalam diri siswa dan faktor eksternal siswa, yaitu segala sesuatu yang berkaitan dengan hal-hal yang bersumber dari luar diri siswa.
\end{abstract}

Kata Kunci : Metode, Kebangkitan, Belajar Siswa

\section{PENDAHULUAN}

\section{A. Latar Belakang Masalah}

$A$ dalah sebuah keniscayaan sejarah peradaban manusia, selalu diawali oleh kemajuan pendidikan. Dinasti Abbasiyah mencapai puncak kejayaannya dikarenakan oleh adanya kesadaran bahwa pendidikan adalah gerbang kemajuan, sehingga salah satu khalifahnya pernah berpesan kepada salah seorang anaknya yang mengatakan bahwa wahai anakku, jika engkau berjalan dan hendak berhenti, maka berhentilah pada dua tempat, yaitu toko penjual senjata atau toko buku. Pernyataan tersebut, jika dianalisa, maka dapat dipahami bahwa tempat perhentian di toko senjata mengisayaratkan tentang beberapa pelajaran penting yang berkaitan dengan alat-alat persenjataan dan tempat perhentian di toko buku jelas memberikan makna bahwa seseorang ; sambil melepas lelah ia dapat melihat, bahkan membaca buku-buku sebagai penambah ilmu pengetahuan.

Namun demikian, akibat perkembangan peradaban di satu sisi, tampak terjadinya pergeseran-pergeseran nilai yang berakibat buruk kepada para peserta didik kita dalam bentuk kurangnya minta lagi untuk belajar. Mereka lebih menyenangi "Kapten Tsubasa daripada pelajaran membaca, mereka lebih memilih "detektif Mori" daripada mereproduksi memori. Bahkan waktu-waktu

\footnotetext{
${ }^{1}$ Dosen STAIM Sinjai
} 


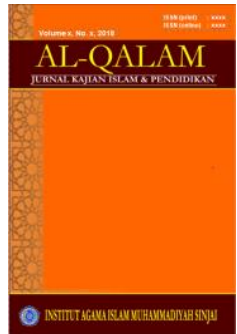

AL-QALAM

Jurmal Kajian Islam \& Pendidikan

Volume 06 No 022014

ISSN (print) : 1858-4152

ISSN (online) : -

Homepage : http://journal.iaimsinjai.ac.id/index.php/al-qalam

sekolah lebih diisi dengan play station di luar sekolah daripada harus duduk belajar di kelas.

Oleh karena itu, sekolah yang berintikan tenaga pengajar atau guru perlu untuk melakukan cara atau metode agar dapat meningkatkan minat belajar pada anak-anak. Hal ini disebabkan karena metode adalah suatu cara yang berfungsi sebagai alat untuk mencapai tujuan pengajaran. Semakin baik metode yang digunakan, maka semakin efektif dan efisien pula pencapaian tujuan suatu pengajaran.

Dengan banyaknya faktor yang mempengaruhi di dalam penggunaan suatu metode, maka sulit menetapkan metode yang baik digunakan dalam pengajaran, sebab ada metode yang baik bagi seorang guru tapi guru yang lain tidak.

Namun demikian terdapat ciri-ciri umum yang dimiliki dalam suatu metode. Dengan memahami ciri masing-masing metode dan prinsip-prinsipumum menajar yang profesional midah menetapkan metode yang efektif yang digunakan dalam belajar mengajar khususnya anak yang mengalami kesulitan dalam mengajar.

Kesulitan belajar tidak tidak hanya terjadi pada siswa yang memiliki intelegensi yang rendah dan intelegensi yang sangat tinggi tetapi juga pada siswa yang berintelegensi yang normal (rata-rata). Kesulitan itu disebabkan oleh faktorfaktor tertentu yang menghambat kinerja akademik sesuai denan harapan.

\section{B. Rumusan Masalah}

Berdasarkan pada latar belakang tersebut, maka penulis akan mengangkat suatu permasalahan, yaitu :

1. Bagaimana pengertian metode mengajar dan prinsip-prinsip mengajar.

2. Bagaimana metode yang efektif untuk menimbulkan minat belajar pada siswa

\section{PEMBAHASAN}

\section{A. Pengertian Metode Mengajar dan Prinsip-Prinsip Mengajar}

Metode secara harfiah berarti cara. Dalam pemikiran umum metode diartikan sebagai cara melakukan pekerjaan yang menggunakan fakta dan konsepkonsep secara sitematis.

Dalam Kamus Bahasa Indonesia, metode diartikan cara yang teratur dan berpikir bak-baik untuk memcapai maksud atau dalam ilmu pengetahuan dan sebagainya. Cara yang bekerja yang bersistem untuk memudahkan pelaksanaan suatu kegiatan guna mencapai tujuan yang ditentukan. ${ }^{2}$ Dalam dunia psikologi metode adalah prosedur sistematis yang bisa digunakan untuk menyelediki

${ }^{2}$ Departemen Pendidkan dan Kebudayaan, Kamus Umum Bahasa Indonesia (Cet. IX ; Jakarta : Balai Pustaka, 1997) h. 652 


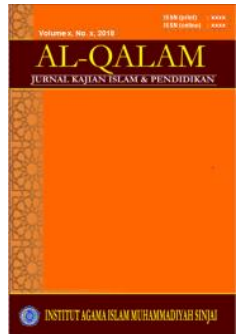

AL-QALAM

Jurmall Kajian Islam \& Pendidikan

Volume 06 No 022014

ISSN (print) : 1858-4152

ISSN (online) : -

Homepage : http://journal.iaimsinjai.ac.id/index.php/al-qalam

fenomena atau gejala-gejala kejiwaan seperti metode klinik, metode eksperimen dan sebagainya. ${ }^{3}$

Muhammad Athiyah Al-Abrasyi mengatakan bahwa metode adalah jalan atau cara yang diikuti untuk memberi paham kepada siswa-siswa segala macam pelajaran dalam segala macam mata pelajaran. ${ }^{4}$

Metode mengajar adalah suatu pengetahuan tentang cara-cara mengajar yang dipergunakan oleh seorang guru atau instruktur. Pengertian lain ialah teknik pengajaran yang dikuasai guru untuk mengajar atau menyajikan bahan pelajaran kepada siswa di dalam kelas, baik secara individual maupun secara klasik, agar pelajaran itu dapat diserap, dipahami, dan dimanfaatkan oleh siswa dengan baik. ${ }^{5}$

Di dalam metode pengajaran terdapat strategi mengajar, yang sesungguhnya melekat, tetapi sering orang melupaknnya. Padahal stratgei itu sangat menyentuh pada perhatian siswa. Metode dan strategi belajar memenag berbeda. Karena metode mengajar tidak langusung berhubungan dengan hasil belajar yang dikehendaki, artinya dibandingkan dengan stategi, metode pada umumnya kurang berorintasi pada tujuan karen ametode dianggap lebih luas daripada strategi. ${ }^{6}$

Pernyataan tersebut di atas, jika dianalisa lebih dalam maka tidaklah berarti bahwa metode tidak signifikan dibandingkan dengan strategi mengajar itu ada dan berlaku dalam kerangka metode mengajar.

Rumusan metode mengajar yang telah dikemukakan oleh para pakar tersebut di atas pada dasarnya sama, oleh karena itu, dapat disimpulkan bahwa metode mengajat ialah cara yang berisi prosedur yang baku yang dapat dipergunakan dalam proses belajar mengajar atau kegiatan kependidikan, khususnya aktivitas penyajian materi pelajaran kepada siswa.

Metode mengajar ini harusa dipelajari oleh setiap guru agar dapat berhasil dalam melaksanakan tugasnya. Makin baik metode mengajar maka makin efektif pula pencapaian tujuan. Efektifitas suatu metode mengajar di kelas sangat dipengaruhi oleh beberapa faktor, antara lain faktor tujuan, faktor siswa, faktor situasi, dan faktor guru itu sendiri.

2. Prinsip-prinsip mengajar

Bila kita memperhatikan berbagai teori-teori belajar an teori-teori mengajar, maka keduanya mengandung beberapa prinsip yang sangat mendukung proses belajar dan mengajar dalam rangka mencapai tujuan yang telah diterapkan. Berdasarkan hal tersebut dapat dilihat pula bahwa pada metode pengajaran pun terdapat prinsip-prinsip umum yang menjadi dasar metode tersebut.

Terdapat beberapa pendapat para ahli atau pakar tentang jumlah prinsipprinsip umum yang mendasar metode mengajar, namun dalam hal ini tidaklah

\footnotetext{
${ }^{3}$ Muhbbin Syah, Psikologi Pendidikan Dengan Pendekatan Baru (Cet. IV ; Bandung : Remaja Rosdakarya, 1999) h. 201

${ }^{4}$ Athiyah Al-Abrasyi, Ruh Al-Tarbiyah (Kairo : Isa Al-Babi Al-Halaby, t.th.) h. 267

${ }^{5}$ Mansyur, Strategi Belajar Mengajar (Jakarta : Dibinperta Islam dan Universitas Terbuka, 1991) h. 134

${ }^{6}$ Muhibbin Syah, Ibid h. 201
} 


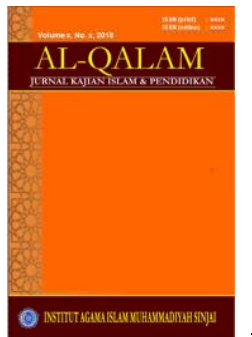

AL-QALAM

Jurmall Kajian Islam \& Pendidikan

Volume 06 No 022014

ISSN (print) : 1858-4152

ISSN (online) : -

Homepage : http://journal.iaimsinjai.ac.id/index.php/al-qalam

dikemukakan semuanya. Adapun yang dapat dikemukakan adalah sebagai berikut

1. Prinsip motivasi dan tujuan

2. Prinsip taraf kematangan dan perbedaan individu

3. Prnsip peluang praktis

4. Prinsip proses belajar mengajar dan menggembirakan.

Guru yang ingin menggunakan metode mengajar, ia harus memperhatikan prinsip-prinsip tersebut di atas. Dengan memperhatikan prinsip-prinsip tersebut, mudah-mudahan guru dapat menetapkan metode sesuai sehingga mampu mencapai tujuan yang diinginkan.

Untuk mengetahui prinsip-prinsip tersebut, maka berikut ini akan dijelaskan satu persatu :

a. Prinsip motivasi dan tujuan

Motivasi merupakan unsur yang paling penting dalam belajar dan paling sulit untuk dukur. Para psikolog memberikan pengertian motivasi sebagai sebuah proses internal yang mengaktifkan, membimbing, dan mempertahankan perlaku sepanjang waktu. Dengan bahasa yang sangat sederhana apa yang membuat anda pergi dan ke mana anda pergi.

Motivasi berbeda dari segi intensitas dan tujuannya, misalnya dua orang siswa termotivasi untuk belajar komputer, namun belum tentu kedua siswa ini memeiliki motivasi untuk belajar komputer

Motivasi siswa, minat, dan keinginannya dalam proses belajar perlu dijaga, seseorang yang bekrja berdasarkan motivasi yang kuat ia tidak akan merasakan lelah dan bosan. Oleh sebab itu, guru perlu memelihara motivasi siswa dan juga segala yang berkaitan dengan motivasinya, seperti kebutuhan, keinginan, dan lain-lain.

Selian guru harus memperhatikan motivasi seperti yang diuarikan di atas, juga ia harus juga memperjhatikan tujuan pengajaran. Dengan memperhatikan tujuan pengajaran guru mudah mencari mencari bahan yang akan diajarkan.

Memangkitkan dan menjada motivasi siswa tidak dapat dipungkiri, bahkan hal itu sangatlah penting. Tanpa motivasi seoarng siswa, maka ia akan belajar atau bekerja tanpa gairah karena tidak ada stimulus yang mendorongnya.

b. Prinsip taraf kematangan dan perbedaan individu.

Setiap guu perlu mengetahui dan memahami tentang taraf kematangan dan taraf kematangan kesediaan belajar seorang siswa, sehingga dengan demikian dia akan mudah menentukan, bagaimana ia harus menghadapi siswa itu, dan menentukan meode apa yang tepat digunakannya.

Tidak ada yang sama, hal ini disebabkan latar belakang kehidupan siswa, bakat dan lingkungannya. Perbedaab ini pada umumnya meliputi:

a. Waktu dan irama perkembangan

b. Motif, intelegensi dan emosi

c. Kecepatan belajar/menangkap pelajaran 


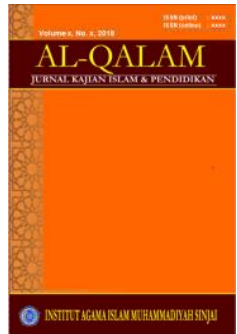

AL-QALAM

Jurmal Kajian Islam \& Pendidikan

Volume 06 No 022014

ISSN (print) : 1858-4152

ISSN (online) : -

Homepage : http://journal.iaimsinjai.ac.id/index.php/al-qalam

\section{d. Bakat dan lingkungan. ${ }^{7}$}

Guru diuntut untuk mengetahui hal tersebut, agar dalam menggunakan metode mengajar, ia harus menyesuaikan dengan perbedaan-perbadaan individu tersebut, maka tujuan pengajaran sulit dicapai, bahkan dapat berakibat negatif bagi siswa.

C. Prinsip Peluang Pengalaman Praktis

Setiap pendidik atau uru seharusnya mempersiapkan peluang partisipasi yang praktis bagi para siswanya, agar apa yang telah dipelajarinya dapat lebih tertanam secara mantap, otentik, tahan lama dan otomatis sifatnya. Tanpa pengalaman [engalaman terhadap ilmu yang diperoleh, maka ilmu tidak akan banyak artinya.

Ada empat prinsip yang perlu dipegang dalam hubungannya dengan peluang partisipasi praktis ini, yaitu :

1. Prinsip partisipasi praktis

2. Prinsip penaksiran arti dan penjelasan yang kongkrit terhadap pengetahuan dan fakta-fakta yang dipelajari

3. Prinsip pengulangan

4. Prinsip teladan yang baik, misalnya Ing ngarso sung tuludo, Ing madya mangung karsa, dan Tut wuri handayani

d. Prinsip belajar fungsional dan menggembirakan

Setiap guru diharapkan mampu menciptakan suasana menggembirakan dalam kegiatan belajar mengajar karenahal ini akan menambah gairah belajar siswa untuk belajar. Sebab salah satu hal yang menyebabkan orang itu giat belajar apabila disertai dengan perasaan senang.E.L. Thorndike mengatakan dalam sebuah hukumnya, yaitu law of effect, hubungan S-R akan bertambah erat jika disertai dengan perasaan senang atau puas, sebaliknya hubungan itu akan berkurang eratnya atau lenyap jika disertai dengan perasaan kecewa atau kurang senang. Oleh karena itu, guru hendaknya berlemah lembut, manusiawi, menghargai siswa, dan tidak tidak bersifat otokratis.

Dengan memperhatikan prinsip-prinsip yang mendasari pemilihan metode tersebut, maka sangat membantu guru untuk menggunakan metode atau cara yang efektif untuk menbatasi siswa yang cenderung tidak memiliki minat untuk belajar.

\section{B. Metode dan Prinsip Mengajar Yang Efektif Untuk Menstimuli Minat Belajar Siswa}

Anak yang memiliki perhatian terhadap pelajaran, disebabkan oleh beberapa faktor. Di dalam psikologi pendidikan ditemukan paling tidak ada dua hal yang seing mempengaruhi anak sehinga tidak berminat untuk belajar, di antaranya :

${ }^{7}$ M. Arifin dan Kartikawati Etti, Bimbingan dan Konseling (Ditbinperta dan Universitas Terbuka, 1992) h. 245 


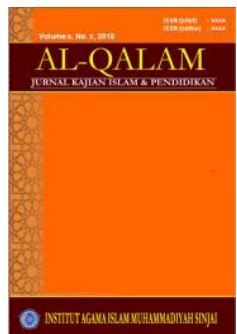

AL-QALAM

Jurmall Kajian Islam \& Pendidikan

Volume 06 No 022014

ISSN (print) : 1858-4152

ISSN (online) : -

Homepage : http://journal.iaimsinjai.ac.id/index.php/al-qalam

1. Faktor intern siswa, yaitu segala sesuatu yang berkaitan dengan hal-hal yang bersumber dari dalam diri siswa.

2. Faktor eksternal siswa, yaitu segala sesuatu yang berkaitan dengan hal-hal yang bersumber dari luar diri siswa.

Kedua faktor tersebut, akan dianalisis oleh penulis secara singkat khususnya yang berkaitan dengan kesulitan belajar yang menyebabkan anak / siswa memiliki cenderung untuk meninggalkan kelas karena tidak berminat terhadap pelajaran. Di samping itu, penulis juga akan memnguraikan secara singkat tentang cara-cara yang efektif untuk mengatasi kurangnya minat belajar siswa.

a. Faktor intern siswa

Sebagaimana telah disebutkan sebelumnya bahwa faktor intren adalah segala sesuatu yang berkaitan dengan hal-hal yang bersumber dari dalam diri siswa. Dalam hal ini, faktor intern terdiri dari dua aspek, yaitu :

1). Aspek fisiologis

Tubuh yang sehat dapat mempengaruhi semangat dan intensitas siswa dalam mengikuti pelajaran. Sebaliknya kondisi tubuh yang lemah atau kurang sehat, seperti pusing-pusing, sakit kepala, inluenza, dan lain-lain akan menurunkan kualitas kognitif anak, sehingga materi yang dipelajarinya tidak berbekas. Siswa yang mengalami hal seperti itu, perlu diberikan instirahat dan memeriksakan diri ke dokter.

Kondisi organ-organ khusus siswa, seperti kesehatan indra pengelihatan mengalami gangguan ringan, juga mempengaruhi kemampuan siswa dalam menyerap informasi dan pengetahuan khususnya yang disajikan di dalam kelas.

Untuk mengatasi masalah yang ditibulkan oleh masalah mata dan telinga, maka guru yang profesional akan menempatkan anak didik pada dertan bangku depan secara bijaksana tanpa memberitahukan alasan ditempatkannya di bangku depan (apalagi jika diekspos di depan umum).

Metode yang ditempuh seperti ini adalah efektif untuk mempertahankan rasa percaya diri anak didik/siswa. Kalau tidak demikian, akan menimbulkan frustasi dan cepat atau lambat peserta didik terebut akan mengalami under achiever atau kemungkinan gagal. Dalam hal ini kegagalan yang dimaksud adalah kegagalan dalam belajar, meskipun siswa tersebut memiliki kapasistas kognitif normal atau lebih tinggi dari teman-temanya.

2) aspek psikologis

Aspek psikologis yang dimaksud dalam hal ini adalah tigkat kecerdasan siswa, sikap siswa, bakat siswa, minat siswa, dan motivasi siswa.

a) Intelegensi siswa

Intelegensi pada umumnya dapat diartikan sebagai kemampuan psiko-fisik untuk mereaksi rangsangan atau bentuk penyesuaian diri dengan lingkungan dengan cara-cara yang tepat.

Tingkat kecerdasan siswa adalah sesuatu yang tidak terbantahkan keberadaannya dalam menentukan keberhasilan siswa. Artinya, semakin cerdas siswa bersangkutan, maka semakin besar peluangnya untuk meraih kesuksesan. 


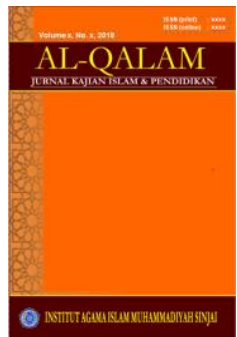

AL-QALAM

Jurmal Kajian Islam \& Pendidikan

Volume 06 No 022014

ISSN (print) : 1858-4152

ISSN (online) : -

Homepage : http://journal.iaimsinjai.ac.id/index.php/al-qalam

Sebaliknya, semakin rendah tingkat intelegensi seorang anak didik, maka akan semakin kecil peluang untuk meraih kesuksesan.

Oleh karena itu, guru yang profesional harus menyadari bahwa keluarbiasaan intelegensi siswa, baik positif maupun negatif akan menimbulkan masalah atau kesulitan untuk belajar. Hal ini dapat ditandai dengan sikap apatis yang diperlihatkan oleh anak-anak yang cerdas dalam mengikuti pelajaran, karena merasa bahwa gurunya tidak memberikan dia tantangan intelektual. Akibatnya, siswa bersangkutan merasa bosan dan akhirnya frustasi karena tuntutan intelegensinya merasa tertekan atau dibendung secara tidak adil. Sebaliknya, siswa yang memiliki intelensi rendah, akan merasa sangat payah untuk mengikuti pelajaran karena dianggapnya sangat susah. Akibatnya, siswa bersangkutan selalu merasa lesu dalam mengikuti pelajaran.

Dengan demikian, metode yang efektif untuk mengatasi anak yang paling cerdas, sebaiknya dinaikkan satu tingkat ke kelas yang sederajat dengan kecerdasannya. Sebaliknya, upaya untuk mengatasi siswa yang tergolong berintelegensi rendah, sebaiknya ditempatkan pada kelas-kelas yang sama dengan tingkat integensinya.

b) Sikap siswa

Sikap adalah gejala internal yang berdimensi efektif, berupa kecenderungan untuk meresponi dengan cara relatif tetap pada objek, baik secara positif maupun secara negatif.

Untuk mengantisipasi kemungkinan munculnya sikap negatif siswa dalam mengikuti pelajaran, maka guru dituntut untuk lebih dahulu menunjukkan sikap positif pada dirinya dan mata pelajaran yang akan diajarkannya, serta penyampaian manfaat yang dapat diterima oleh siswa pada mata pelajaran itu.

c) Bakat siswa

Secara umum bakat adalah kemampuan potensial yang dimiliki seseorang untuk mencapai keberhasilan masa yang akan datang. Setiap orang memiliki bakat sendiri-sendiri. Bakat dapat memberikan pengaruh pada pencapaian prestasi belajar seseorang pada bidang-bidang tertentu. Oleh karena itu, jika ada orang tua yang memaksakan anaknya pada jurusan atau sekolah tertentu tanpa didasarkan pada bakat-bakat anak-anak itu. Apabila seseorang dipaksakan memasuki suatu sekolah atau bidang-bidang tertentu, maka akan menimbulkan keapatisan anak mengikuti seluruh program pengajaran.

b. Faktor ekstern siswa

Faktor ekstern siswa meliputi semua situasi dan kondisi lingkungan, baik lingkungan sosial maupun lingkungan nonsosial yang tidak mendukung minat aktivitas belajar siswa bahkan akan menghilangkan kegairahan mereka untuk belajar.

Faktor ini dapat dibagi atas tiga bahagian, yaitu :

1. Lingkungan keluarga, contohnya ketidak harmonisan keluarga dan rendahnya tingkat ekonomi keluarga

2. Lingkungan perkampungan kumuh (slum area) dan teman sepermainan yang nakal 


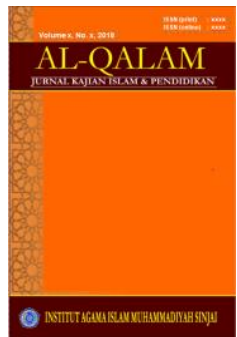

AL-QALAM

Jurmal Kajian Islam \& Pendidikan

Volume 06 No 022014

ISSN (print) : 1858-4152

ISSN (online) : -

Homepage : http://journal.iaimsinjai.ac.id/index.php/al-qalam

3. Lingkungan sekolah, misalnya kondisi dan letak gedung sekolah yang buruk, seperti dekat dengan bengkel, pasar, kondisi guru dan alat belajar yang tidak memadai. ${ }^{8}$

Ketiga faktor tersebut perlu mendapat penanganan yang serius agar anak terlepas dari kesulitan belajar. Hal ini disebabkan betapa banyak siswa yang mengalami kesulitan belajar dalam arti minat mereka menurun disebabkan oleh salah satu atau bahkan ketiga-tiga jenis lingkungan tersebut.

Oleh karena itu, untuk menggairahkan minat belajar anak-anak dari pengaruh lingkungan, maka layanan bimbingan dan konseling di sekolah harus dilakukan secara optimal. Hal ini dilakukan agar para siswa dapat diberikan opemecahan atas masalah yang mengakibatkan kurangnya minat belajar mereka.

\section{P E N U T U P}

\section{A. Kesimpulan}

Berdasarkan pembahasan yang dilakukan oleh penulis, maka pada bahagian ini penulis akan memberikan kesimpulan sebagai berikut:

1. Metode mengajar adalah adalah suatu pengetahuan tentang cara-cara mengajar yang dipergunakan oleh seorang guru atau instruktur. Pengertian lain ialah teknik pengajaran yang dikuasai guru untuk mengajar atau menyajikan bahan pelajaran kepada siswa di dalam kelas, baik secara individual maupun secara klasik, agar pelajaran itu dapat diserap, dipahami, dan dimanfaatkan oleh siswa dengan baik. Sedangkan prinsip-prinsip mengajar meliputi prinsip motivasi dan tujuan, prinsip taraf kematangan dan perbedaan individu, prinsip peluang praktis, dan prinsip proses belajar mengajar dan menggembirakan.

2. Metode efktif untuk memberikan stimuli minat belajar siswa, maka seorang guru harus memperhatikan dua fakyor, yaitu faktor intern siswa, yaitu segala sesuatu yang berkaitan dengan hal-hal yang bersumber dari dalam diri siswa dan faktor eksternal siswa, yaitu segala sesuatu yang berkaitan dengan hal-hal yang bersumber dari luar diri siswa.

\section{DAFTAR PUSTAKA}

Al-Abrasyi, Athiyah. Ruh Al-Tarbiyah, Kairo : Isa Al-Babi Al-Halaby, t.th

Arifin, M. dan Kartikawati Etti, Bimbingan dan Konseling, Ditbinperta dan Universitas Terbuka, 1992

Ashari, M. Hafi. Pengantar Ilmu Pendidikan, Surabaya : Usaha Nasional, 1983

${ }^{8}$ M. Hafi Ashari, Pengantar Ilmu Pendidikan (Surabaya : Usaha Nasional, 1983) h. 92 


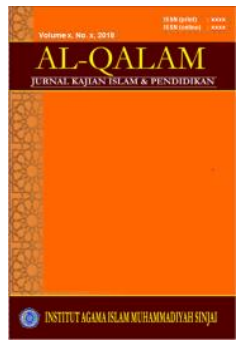

AL-QALAM

Jurnal Kajian Islam \& Pendidikan

Volume 06 No 022014

ISSN (print) : 1858-4152

ISSN (online) : -

Homepage : http://journal.iaimsinjai.ac.id/index.php/al-qalam

Departemen Pendidkan dan Kebudayaan, Kamus Umum Bahasa Indonesia (Cet. IX ; Jakarta : Balai Pustaka, 1997) h. 652

Mansyur, Strategi Belajar Mengajar (Jakarta : Dibinperta Islam dan Universitas Terbuka, 1991) h. 134

Syah, Muhbbin. Psikologi Pendidikan Dengan Pendekatan Baru, Cet. IV ; Bandung : Remaja Rosdakarya, 1999 